\title{
The pathological diagnosis of nerve biopsies: a practical approach
}

\section{Sebastian Brandner}

Is Professor of Neuropathology at the Institute of Neurology, University College London and Consultant Neuropathologist at the National Hospital for Neurology and Neurosurgery, University College London Hospitals NHS Foundation Trust, Queen Square, London WC1N 3BG.

Conflicts of interest: none declared.

\begin{abstract}
The approach to the neuropathological assessment of nerve biopsies is the main focus of this review. Nerve biopsies are invasive diagnostic procedures resulting in a permanent neurological deficit, and are therefore carried out only following an in-depth clinical assessment including laboratory, imaging, electrophysiological, and where appropriate also genetic studies. This review will outline the key diagnostic approaches and will discuss neuropathies relevant in clinical practice, caused by vasculitis, inflammatory demyelination, dysproteinaemic, amyloid, toxic agents, and neuropathies due to genetic conditions.
\end{abstract}

\section{Introduction}

This review considers nerve pathology in the context of diagnostic nerve biopsies as part of the clinical workup. Therefore, the focus of this review is the diagnostic approach with practical considerations for the preparation, processing and staining of samples and an appraisal of the use of different techniques to achieve a clinically relevant and meaningful diagnosis. An overview of the pathology of the most common peripheral neuropathies will be provided.

Peripheral neuropathies can be acquired or genetic, and have an acute, subacute or insidious (chronic) onset. They can present at any age with no gender predilection. Whilst nerve conduction studies are helpful in differentiating axonal from demyelinating neuropathies in most instances, occasionally the interpretation can be difficult. Furthermore, NCS do not inform about the underlying cause of either axonal or demyelinating neuropathy. Laboratory tests, such as assessment of antibody titres can suggest inflammatory, dysproteinaemic or infiltrative processes, but are not confirmatory on their own. The treatment options vary depending on the underlying pathology, hence the necessity of a nerve biopsy.

\section{Indication for nerve biopsies:}

The ENMC International workshop ${ }^{1}$ defined the following for patients groups in an attempt to define indications for nerve biopsies:

1) Patients in whom sural nerve biopsy will be diagnostically helpful

2) Patients in whom sural nerve biopsy will have therapeutic implications

3) Patients who will definitely not benefit from sural nerve biopsy

4) Patients who are at risk for complications from sural nerve biopsy.

Sural nerve biopsy is helpful in inflammatory and dysimmune neuropathies, specifically vasculitis and chronic inflammatory demyelinating neuropathy, possibly in leprosy and some forms of genetic 
neuropathies (which over time are increasingly replaced by genetic testing of the patient). A nerve biopsy is more often diagnostic in acute and subacute forms than chronic forms.

The indication for the biopsy of a peripheral nerve can vary according to the clinical context and is strongly indicated in many conditions such as acute or subacute multiple mononeuropathies, subacute, or chronic axonal sensory motor polyneuropathies with rapid revolution, in CIDP in patients where clinical and electrophysiological features are compatible with a diagnosis but where additional clinical symptoms raise the possibility of additional diseases, and in the final step in the diagnostic work up of a neuropathy of unknown origin.

\section{Acquisition and preparation of samples}

The specimen should be obtained from an affected nerve. The most common biopsy site is the sural nerve, as it is relatively easy to access surgically. The sural nerve is purely sensory in more than $90 \%$ of patients and contains only few motor fibres in the remaining patients ${ }^{2}$. A biopsy of the sural nerve will result in a permanent deficit, which is independent of the length of the specimen and therefore at least $4 \mathrm{~cm}$ should be obtained. Because nerve biopsy is invasive, costly and associated with possible morbidity, it is highly recommended that sufficient tissue is taken so that multiple blocks of tissue can be embedded. Removal of shorter segments will be less useful diagnostically and may limit the diagnostic value. After excision, the biopsy has to be handled with care in order to minimise mechanical injury to the sample.

The nerve biopsy should be divided (transversely) and one part should be formalin-fixed and another glutaraldehyde fixed. The formalin-fixed and paraffin processed specimen should contain representative longitudinal and transverse sections. A portion of the glutaraldehyde fixed nerve will be processed into resin for the preparation of semithin resin sections and optional subsequent electron microscopy. A further proportion should be kept for optional subsequent preparation of teased fibres.

A normal sural nerve usually comprises between five and ten nerve fascicles. In a large autopsy study, 3300-8000 myelinated and 10,500-45,500 unmyelinated nerve fibres were found in subjects without history of disease or ingestion of drugs known to affect peripheral nerve ${ }^{3}$.

Laboratories performing nerve biopsies should have the facilities and technology to prepare semithin resin sections and teased fibres or have collaborative arrangements in place to access such preparations.

\section{Staining for morphological assessment in routine practice}

Recommendations for the assessment of peripheral nerve biopsies have been published in guideline documents ${ }^{4-7}$. Formalin-fixed and paraffin processed samples are ideal for further analysis by tinctorial and immunohistochemical stainings. These can be carried out in most histopathology laboratories, even without access to specialist techniques. Essential tinctorial stainings are the classical Haematoxylin and Eosin (H\&E) and Congo red. The basic assessment on H\&E sections will immediately inform about inflammatory infiltrates, and significant active axon degeneration. H\&E staining can also inform about gross loss of myelinated fibres and extensive formation of de-and remyelinating Schwann cell bulbs (onion bulbs) and other characteristic abnormalities such as perineurioma, and infiltration of lymphoma or other malignancies. Congo red staining is essential for the detection of endoneurial amyloid. Multiple sections on several levels are highly recommended, in particular to detect inflammatory infiltrates, which often are irregularly distributed within a 
biopsy. In our practice, we perform 30 serial sections ( $4 \mu \mathrm{m}$ nominal thickness each) and stain sections 1, 10, 20 with H\&E and keep all sections for subsequent immunostainings or as reserve unstained sections for future investigations. A pearls iron staining is optional to detect haemosiderin deposits in vasculitic or post-vasculitic neuropathies. Wade-Fite tinctorial staining is relevant if features of leprosy are seen in the biopsy or suggested clinically.

Immunohistochemical stainings should include those for axons (usually neurofilament) and myelin (e.g. myelin basic protein). These are helpful to determine the overall axon population, and the myelin staining will give additional information about the population of large and small myelinated fibres. These two stainings are particularly useful to complement the assessment on semithin resin sections on which unmyelinated fibres are difficult to assess semiquantitatively. Myelin staining is essential if semithin resin sections are not available. Inflammatory markers should at comprise B-and T-cell markers such as CD3, CD8 and CD20. Staining for the plasma cell marker CD138 can in certain conditions be helpful. Staining for the macrophage marker CD68 is essential to assess the overall endoneurial macrophage population and activity. CD68 labelling is essential to assess the extent of the overall endoneurial macrophage activity and the severity of axonal degeneration.

The semithin resin section is an important adjunct preparation for a more detailed morphological assessment of myelin structure, endoneurial oedema, loss of fibres, and assessment of degenerating axon profiles in acute and subacute axonal neuropathies. In our practice, only transverse sections are prepared whilst longitudinal sections in our opinion do not add much additional information. Resin semithin sections are prepared from glutaraldehyde fixed specimen and usually stained with Toluidine blue or Methyl Blue Aniline-Basic Fuchsine - MBA-BF).

Electron microscopy is essential to determine the nature of myelin abnormalities such as widely spaced myelin, uncompacted myelin, assess and specified myelination disorders, in particular in the context of dysimmune and genetic forms.

The assessment of myelin sheath abnormalities (axon degeneration, segmental de- and remyelination can be further aided by the preparation of teased fibres, which allow the full longitudinal assessment of individual axons.

The preparation of Frozen sections is optional in our opinion, and have been replaced in most laboratories by paraffin sections. Frozen sections require a more involved preparation process and the availability of a wide range of antibodies suitable for formalin-fixed paraffin embedded (FFPE) tissue sections has made frozen sections largely redundant in most laboratories.

\section{Basic diagnostic approach:}

The main basic alterations in the peripheral nervous system comprise maldevelopment of axons and/or Schwann cells, segmental de-myelination and remyelination, axonal degeneration and regeneration, and loss of entire nerve fibres (comprising axons and Schwann cells) with eventual loss of the hostneuron. The neuropathological assessment typically distinguishes neuropathies as primarily axonal; neuronal; primarily demyelinating, and combined axonal and demyelinating neuropathies (Table 1).

\begin{tabular}{|l|l|l|l|}
\hline Description & Cause & $\begin{array}{l}\text { Pathophysiological } \\
\text { /neurological } \\
\text { change }\end{array}$ & Pathological changes \\
\hline
\end{tabular}




\begin{tabular}{|c|c|c|c|}
\hline Wallerian degeneration & $\begin{array}{l}\text { Physical interruption of } \\
\text { the healthy axon. } \\
\text { Changes occur distal to } \\
\text { the transaction site }\end{array}$ & $\begin{array}{l}\text { Complete paralysis } \\
\text { and sensation loss } \\
\text { in territory of the } \\
\text { nerve trunk }\end{array}$ & $\begin{array}{l}\text { Axon and myelin } \\
\text { sheath degenerate } \\
\text { distal to transaction } \\
\text { site. Regeneration } \\
\text { clusters during } \\
\text { recovery phase }\end{array}$ \\
\hline $\begin{array}{l}\text { Segmental } \\
\text { demyelination }\end{array}$ & $\begin{array}{l}\text { Damage to myelin } \\
\text { sheath but not the } \\
\text { axon }\end{array}$ & $\begin{array}{l}\text { Slowing or } \\
\text { blocking of nerve } \\
\text { conduction. }\end{array}$ & $\begin{array}{l}\text { Segmental } \\
\text { demyelination, } \\
\text { remyelination and } \\
\text { during recovery phase } \\
\text { remyelination }\end{array}$ \\
\hline Axonal degeneration & $\begin{array}{l}\text { Ischaemic, metabolic } \\
\text { or toxic }\end{array}$ & $\begin{array}{l}\text { Paralysis, } \\
\text { proportional to } \\
\text { axon loss, } \\
\text { symmetric distal } \\
\text { sensorimotor } \\
\text { deficit in lower } \\
\text { limbs }\end{array}$ & $\begin{array}{l}\text { Distal breakdown of } \\
\text { axons. }\end{array}$ \\
\hline Neuronopathy & $\begin{array}{l}\text { Lesion in the parent } \\
\text { nerve cell body }\end{array}$ & $\begin{array}{l}\text { Motor neuropathy } \\
\text { (anterior horn cell) } \\
\text { or sensory } \\
\text { ganglionopathy } \\
\text { (sensory ganglia) }\end{array}$ & $\begin{array}{l}\text { Loss of entire nerve } \\
\text { fibres, no regeneration }\end{array}$ \\
\hline
\end{tabular}

\section{Inflammatory neuropathies}

Inflammatory neuropathies can be axonal, such as vasculitic neuropathy, or demyelinating, such as acute (Guillain-Barre syndrome (GBS)) or chronic inflammatory demyelinating neuropathy (CIDP).

Vasculitic neuropathy is the most common inflammatory cause of a neuropathy.

Clinically, these can be of acute, subacute and chronic onset and often are painful and multifocal. It affects the peripheral nerve vasculature, resulting in ischaemic damage to the nerve. In most cases these are caused by systemic or autoimmune mechanisms, often in the context of a systemic connective tissue disease. A vasculitis may be restricted to peripheral nerve blood vessels, resulting in non-systemic vasculitic neuropathy. In most cases however, the involvement of the peripheral nervous system is part of a wider spectrum of organ manifestations. Morphologically, infiltration of vessel walls by $T$ cells and macrophages causes vascular damage and predominantly axon fibre changes.

Microscopically it is useful to distinguish vascular changes, alterations of the nerve and characteristics of the inflammatory infiltrates.

Vascular changes and morphological criteria for vasculitis: The diagnostic consensus criteria for pathologically definite or probable vasculitic neuropathy were published by the Peripheral Nerve Society ${ }^{8}$. A definite vasculitic neuropathy is defined by an inflammation within the vessel wall and signs of active or chronic vascular damage, whilst perivascular or mural inflammation alone is considered non-specific. A probable vasculitic neuropathy can be diagnosed when there is a predominantly axonal damage and (a) perivascular inflammation with active or chronic vessel 
damage or (b) (peri-) vascular inflammation in combination with one of the following five histological predictors of vasculitic neuropathy: (i) vascular IgM, complement or fibrinogen deposits by immunofluorescence, (ii) haemosiderin deposits, (iii) patchy/multifocal nerve fibre loss or (iv), prominent axon degeneration. The following features are supportive but not specific: perineurial thickening, neovascularisation, endoneurial haemorrhage. Vasculitis of endoneurial vessels is uncommon.

Pathological changes in the nerve: A primary axonal process in the endoneurium, with prominent Wallerian-type axonal degeneration, clusters of regenerating fibres and often some endoneurial oedema. Typically, the distribution of axon loss is patchy and can vary between fascicles and within fascicles. Longitudinal sections show myelin degeneration products, and macrophage stains show active myelin digestion by macrophages.

Inflammation: Perivascular inflammation is a common and non-specific finding in nerve biopsies and must be clearly distinguished from vasculitis (see above). Intramural leukocytes can be suggestive, but is not diagnostic within of vasculitis. Inflammatory cells are predominantly T cells with a much smaller proportion of B cells. Occasional endoneurial inflammatory cells can be seen. The multiple clinical manifestations and pathological presentations of inflammatory neuropathies are listed in Table 2.

\begin{tabular}{|c|c|c|}
\hline Neuropathy & $\begin{array}{l}\text { Pathogenesis and } \\
\text { occurrence }\end{array}$ & Clinical presentation \\
\hline Mononeuritis multiplex & $\begin{array}{l}\text { Most common and classic } \\
\text { manifestation of vasculitic } \\
\text { neuropathy }\end{array}$ & $\begin{array}{l}\text { Rapid onset of pain, } \\
\text { paraesthesia. Distribution of a } \\
\text { single nerve trunk evolving } \\
\text { over hours to days }\end{array}$ \\
\hline $\begin{array}{l}\text { Nonsystemic (isolated) } \\
\text { peripheral nervous system } \\
\text { vasculitis }\end{array}$ & $\begin{array}{l}\text { Heterogeneous pathogenesis. } \\
\text { Includes non-diabetic radiculo- } \\
\text { plexus neuropathy }\end{array}$ & $\begin{array}{l}\text { Subacute or chronic } \\
\text { neuropathy often with a } \\
\text { mononeuritis multiplex with } \\
\text { few or no systemic } \\
\text { abnormalities, history or } \\
\text { laboratory investigation }\end{array}$ \\
\hline $\begin{array}{l}\text { ANCA associated microscopic } \\
\text { polyangiitis }\end{array}$ & $\begin{array}{l}\text { Necrotising vasculitis affecting } \\
\text { predominantly small vessels. }\end{array}$ & $\begin{array}{l}\text { Rapidly progressive } \\
\text { glomerulonephritis, pulmonary } \\
\text { involvement and purpura due } \\
\text { to cutaneous vasculitis }\end{array}$ \\
\hline $\begin{array}{l}\text { Classic polyarteritis nodosa } \\
\text { (PAN) }\end{array}$ & $\begin{array}{l}\text { Necrotising arteritis associated } \\
\text { with fibrinoid vessel wall } \\
\text { necrosis. Often associated with } \\
\text { hepatitis B or C infections. } \\
\text { ANCA positivity excludes PAN }\end{array}$ & \\
\hline Churg Strauss angiitis, & $\begin{array}{l}\text { Also known as eosinophilic } \\
\text { granulomatosis with } \\
\text { polyangiitis. ANCA associated) }\end{array}$ & $\begin{array}{l}\text { Prominent pulmonary } \\
\text { symptoms and eosinophilia. } \\
\text { Half of patients develop } \\
\text { vasculitic neuropathy }\end{array}$ \\
\hline $\begin{array}{l}\text { Granulomatosis with } \\
\text { polyangiitis (previously } \\
\text { Wegener's granulomatosis) }\end{array}$ & $\begin{array}{l}\text { Systemic disease with } \\
\text { necrotising granulomata } \\
\text { rather than a primary } \\
\text { vasculitis. ANCA associated }\end{array}$ & $\begin{array}{l}\text { The most common } \\
\text { neurological manifestation is a } \\
\text { neuropathy with mononeuritis } \\
\text { multiplex pattern in } 10 \text { to } 20 \% \\
\text { of patients }\end{array}$ \\
\hline Henoch-Schönlein Purpura & $\begin{array}{l}\text { Systemic vasculitis involving } \\
\text { small vessels, dominantly of }\end{array}$ & $\begin{array}{l}\text { Peripheral nerves are rarely } \\
\text { affected }\end{array}$ \\
\hline
\end{tabular}




\begin{tabular}{|l|l|l|}
\hline & $\begin{array}{l}\text { skin, gastrointestinal tract and } \\
\text { renal glomeruli }\end{array}$ & Systemic disorder \\
\hline Behçet disease & $\begin{array}{l}\text { Peripheral nerves are rarely } \\
\text { affected but when involved } \\
\text { typically presenting as } \\
\text { mononeuritis multiplex }\end{array}$ \\
\hline Connective tissue diseases & $\begin{array}{l}\text { Vasculitic neuropathy in } \\
\text { addition to systemic specific } \\
\text { syndrome associated } \\
\text { involvements }\end{array}$ & $\begin{array}{l}\text { Rheumatoid arthritis when } \\
\text { accompanied by neuropathy } \\
\text { indicate a poor prognosis } \\
\text { Sjogren syndrome is more } \\
\text { commonly associated with a } \\
\text { distal sensorimotor } \\
\text { neuropathy. Lupus } \\
\text { erythematodes is associated } \\
\text { with a neuropathy in 20\% of } \\
\text { cases. }\end{array}$ \\
\hline \multicolumn{2}{|l|}{$\begin{array}{l}\text { Table 2: pathogenesis and occurrence of the most common vasculitic neuropathies. Associated } \\
\text { clinical presentation in the right column. }\end{array}$} & \multicolumn{2}{|l}{} \\
\hline
\end{tabular}

\section{Guillain-Barre syndrome and chronic inflammatory demyelinating polyradiculoneuropathy}

The inflammatory demyelinating neuropathies comprise the Guillain-Barre syndrome (GBS) and the chronic inflammatory demyelinating polyradiculoneuropathy (CIDP). GBS presents as rapidly progressive neuropathy with sensory autonomic and motor dysfunction. Several subtypes have been described including the acute inflammatory demyelinating neuropathy (AIDP), acute motor axonal neuropathy (AMAN) and the acute motor and sensory axonal neuropathy (AMSAN).

Clinically, GBS shows a monophasic course and rapid progression, with a peak deficit over a few hours to four weeks. In classical GBS the progressive motor and sensory deficits affect more than one limb; hypo- or areflexia is prominent ${ }^{9}$. Half of the patients show an ascending pattern of paralysis. Cranial nerves, particularly the facial nerves are commonly involved.

Clinical diagnostic criteria for CIDP include (i) evolution over more than 2 months, (ii) progressive or relapsing/remitting course, (iii) motor and/or sensory symptoms and signs, and (iv) hypo-or areflexia. Involvement is usually symmetrical. Motor symptoms involving proximal and distal muscles often predominate and half of the patients have cranial nerve palsies, most often involving the facial nerve. CSF protein is elevated and cell count is normal. Nerve conduction studies show a demyelinating process ${ }^{10,11}$. In the majority of GBS cases, nerve biopsy is not required for diagnosis. In cases where GBS is asymmetric or predominantly axonal, a nerve biopsy may be indicated to exclude vasculitis.

Neuropathological findings: Classic GBS is characterised by active macrophage-associated demyelination and secondary axonal degeneration leading to variably severe fibre loss. AIDP is characterised by complement deposition on Schwann cells, a mononuclear inflammatory infiltrate in the endoneurium and surrounding epineurial blood vessels. Teased fibres help identifying widening of the nodal gap. Axon loss can occur as a bystander effect. Axonal GBS (AMAN and AMSAN) shows predominant axonal degeneration, often with a remarkable absence of inflammatory infiltrates. In 
CIDP a nerve biopsy is particularly indicated in cases of atypical presentation. The classical finding of inflammation and de-and re-myelination is seen only in a proportion of biopsies. In such cases there is primary demyelinating with frequent thinly myelinated axons and Schwann cell bulb formations indicative of chronic de-and remyelination. Often the involvement is patchy across different fascicles, resulting in a multifocal rather than diffuse picture. Inflammatory infiltrates can be highly variable. Teased fibre preparations and ultrastructural examinations can further facilitate detection of de- and remyelination and the latter is also useful to identify macrophage mediated demyelination. A meta analysis of pathological features in CIDP is shown in Figure 1.

\section{Dysproteinaemic/paraproteinaemic neuropathies (polyneuropathy associated with a monoclonal gammopathy)}

These neuropathies are associated with circulating paraprotein, either the entire immunoglobulin molecule or only heavy or light chains. The two most common are anti-MAG neuropathy and a neuropathy as part of the POEMS syndrome (polyneuropathy, organomegaly, endocrinopathy, monoclonal gammopathy, and skin changes), multiple myeloma, Waldenström's disease, Castleman's disease, light chain amyloidosis and the MGUS (monoclonal gammopathy of unknown significance). More than $80 \%$ of the patients with IgM paraprotein are male and typically in the $6^{\text {th }}$ or $7^{\text {th }}$ decade of life (Table 3 ).

Neuropathological assessment should separate inflammation and nerve pathology. In paraprotein associated neuropathies there can be focal, epineurial or endoneurial infiltrates of lymphocytes, macrophages and occasionally plasma cells. The nerve pathology shows demyelination with active myelin breakdown, thinly myelinated fibres, and axon degeneration and regeneration. Chronic forms of IgM paraprotein associated neuropathies show chronic de- and remyelinating features. Electron microscopy shows widely spaced myelin (separation of paired membranes from 2 to $4 \mathrm{~nm}$ to 20 to $30 \mathrm{~nm}){ }^{12}$. In POEMS there is usually little or no inflammation and the neuropathy includes axon degeneration, segmental demyelination with the possible overlap of both pathologies. Electron microscopy can show uncompacted myelin, caused by the lack of the fusion of Schwann cell membranes and axons wrapped in spirals of Schwann cell cytoplasm ${ }^{13}$ Table 4.

\begin{tabular}{|l|l|l|l|}
\hline Syndrome & Pathogenesis/Laboratory & Clinical & Pathology \\
\hline POEMS & $\begin{array}{l}\text { Clonal expansion of } \\
\text { lymphocyte/plasma cells, } \\
\text { secretion of monoclonal } \\
\text { immunoglobulin (IgG> } \\
\text { IgM> IgA). }\end{array}$ & $\begin{array}{l}\text { Distal, sensorimotor, } \\
\text { symmetrical neuropathy } \\
\text { progressing over months } \\
\text { or years. Can resemble } \\
\text { clinically to } \\
\text { polyradiculoneuropathy } \\
\text { or mononeuritis } \\
\text { multiplex. Can progress in } \\
\text { a subacute, stepwise or } \\
\text { relapsing/remitting } \\
\text { fashion. }\end{array}$ & $\begin{array}{l}\text { Little } \\
\text { inflammation, } \\
\text { axon } \\
\text { degeneration, } \\
\text { segmental } \\
\text { demyelination, } \\
\text { ultra } \\
\text { structurally } \\
\text { uncompacted } \\
\text { myelin }\end{array}$ \\
\cline { 3 - 5 } $\begin{array}{l}\text { Waldenstrom's } \\
\text { macroglobulinaemia }\end{array}$ & $\begin{array}{l}\text { Transformation of } \\
\text { monoclonal lgM producing } \\
\text { lymphocytes into a } \\
\text { lymphoproliferative } \\
\text { disorder. Anti-myelin } \\
\text { associated glycoprotein }\end{array}$ & & $\begin{array}{l}\text { Demelination, } \\
\text { myelin } \\
\text { breakdown } \\
\text { axon de- and } \\
\text { regeneration. } \\
\text { Ultra }\end{array}$ \\
\hline
\end{tabular}




\begin{tabular}{|l|l|l|}
\hline & $\begin{array}{l}\text { (MAG) antibodies. CSF } \\
\text { protein increased, nerve } \\
\text { conduction studies } \\
\text { demyelinating or mixed } \\
\text { features }\end{array}$ & $\begin{array}{l}\text { structurally } \\
\text { Widely spaced } \\
\text { myelin }\end{array}$ \\
\hline $\begin{array}{l}\text { Table 3: pathogenesis, clinical presentation and key pathological findings in POEMS and } \\
\text { Waldenstrom's macroglobulinaemia. }\end{array}$ \\
\hline
\end{tabular}

\begin{tabular}{|l|l|l|l|l|}
\hline Disease & $\begin{array}{l}\text { Most commonly } \\
\text { associated } \\
\text { paraprotein } \\
\text { IgG>IgM>IgA }\end{array}$ & Neuropathy & Pathology & Reference \\
\hline MGUS & $\begin{array}{l}\text { IgG or IgA } \\
\text { lambda }\end{array}$ & $\sim 50 \%$ & Nerve: * & 14 \\
\hline POEMS & IgM kappa & $\sim 50 \%$ & $\begin{array}{l}\text { Uncompacted } \\
\text { myelin in a } \\
\text { proportion }\end{array}$ & 13 \\
\hline $\begin{array}{l}\text { Waldenström's } \\
\text { macroglobulinaemia }\end{array}$ & $\begin{array}{l}\text { Bone marrow: } \\
\text { Lymophoplasmocytic } \\
\text { infiltration } \\
\text { Nerve: * }\end{array}$ & 15 \\
\hline $\begin{array}{l}\text { Multiple myeloma } \\
\text { IgG kappa } \\
\text { IgM rarely }\end{array}$ & $\begin{array}{l}\text { Bone marrow } \\
\text { biopsy: plasma cell } \\
\text { proliferation } \\
\text { Nerve: * }\end{array}$ & 15 \\
\hline $\begin{array}{l}\text { Amyloidosis (Light } \\
\text { chain deposition } \\
\text { disease }\end{array}$ & $\begin{array}{l}\text { IgG or IgA } \\
\text { lambda }\end{array}$ & $\begin{array}{l}\text { Amyloid deposition, } \\
\text { Congo red-negative } \\
\text { Nerve: * }\end{array}$ & 16 \\
\hline $\begin{array}{l}\text { Table 4: neuropathies associated with paraprotein (NAP), with most commonly associated } \\
\text { paraprotein, the reported frequencies of neuropathies and the salient pathologies. }\end{array}$ \\
* The nerves in NAP often show focal, epineurial and endoneurial infiltrates of lymphocytes and \\
$\begin{array}{l}\text { macrophages. The pathological findings in NAP depend more on the heavy chain type (IgG/IgA vs } \\
\text { IgM) than on the underlying disease (i.e. MGUS, POEMS, WM, MM). }\end{array}$ \\
\hline
\end{tabular}

\section{Amyloid neuropathies}

Amyloid neuropathies occur in the context of acquired or genetic systemic amyloidosis which results from the deposition of misfolded insoluble protein. Neuropathies are usually distantly accentuated and symmetrical, but multiple mono neuropathies may also occur. The neuropathy is predominantly of the axonal type, affecting unmyelinated and small myelinated fibres initially and large myelinated fibres at later stages.

Primary amyloidosis is a chronic haematological disorder manifesting as multisystem disease. It is caused by plasma cell dyscrasia or B cell lymphoproliferative disorders. Amyloid fibrils derive from immunoglobulin light chains and progressively accumulate in heart, kidney, liver and gastrointestinal tract. Neural involvement is present in 20 to $30 \%$ of patients with primary amyloidosis. 
Familial amyloid polyneuropathies (FAP) are autosomal dominant. The most common form, transthyretin amyloidosis is caused by a spectrum of 120 described gene mutations of this liverproduced protein. It develops most commonly from the $3^{\text {rd }}$ to the $6^{\text {th }}$ decade of life ${ }^{17,18}$ and most commonly starts with sensory and autonomic disturbances and other neuropathic symptoms. However, mononeuropathies affecting proximal nerves can occur and carpal tunnel syndrome is frequent.

A mutation in the Apolipoprotein A1 gene (G26A) is associated with a length dependent peripheral neuropathy. Clinically, these neuropathies are phenotypically similar to FAP TTR VF30M ${ }^{19}$. A rare amyloid neuropathy is caused by mutant Gelsolin, an actin modulating protein, affecting axonal transport, myelination, neural outgrowth and neuroprotection. The most common mutations are D187N and D87Y. It starts in the $3^{\text {rd }}$ of $4^{\text {th }}$ decade of life and often shows a distinctive prominent cranial nerve involvement, which may progress to severe bulbar paresis in old age.

Microscopically there is no significant difference between the neuropathological features of familial amyloid neuropathies and primary amyloidosis. Amyloid in a peripheral nerve is always pathological and allows diagnosis of an amyloid neuropathy. Amyloid accumulates in the endoneurium, perineurium and epineurium and is detected by the Congo red and/or thioflavin S or T stains and is best identified when forming large pools. Diffuse distribution may be more difficult to identify. Other deposits can be found in vessel walls or perivascular. The neuropathy is characterised by chronic progressive axonal degeneration. At early stages, unmyelinated and small myelinated fibres are selectively lost and at later stages large myelinated fibres are also affected. Ultrastructurally, amyloid consists of 7 to $10 \mathrm{~nm}$ wide, straight and branched fibrils.

The neuropathological differential diagnosis of amyloid neuropathy includes CIDP and other inflammatory neuropathies. A structural differential diagnosis to amyloid deposits are oxytalan fibres which can be found in Renaut bodies ${ }^{20}$. 


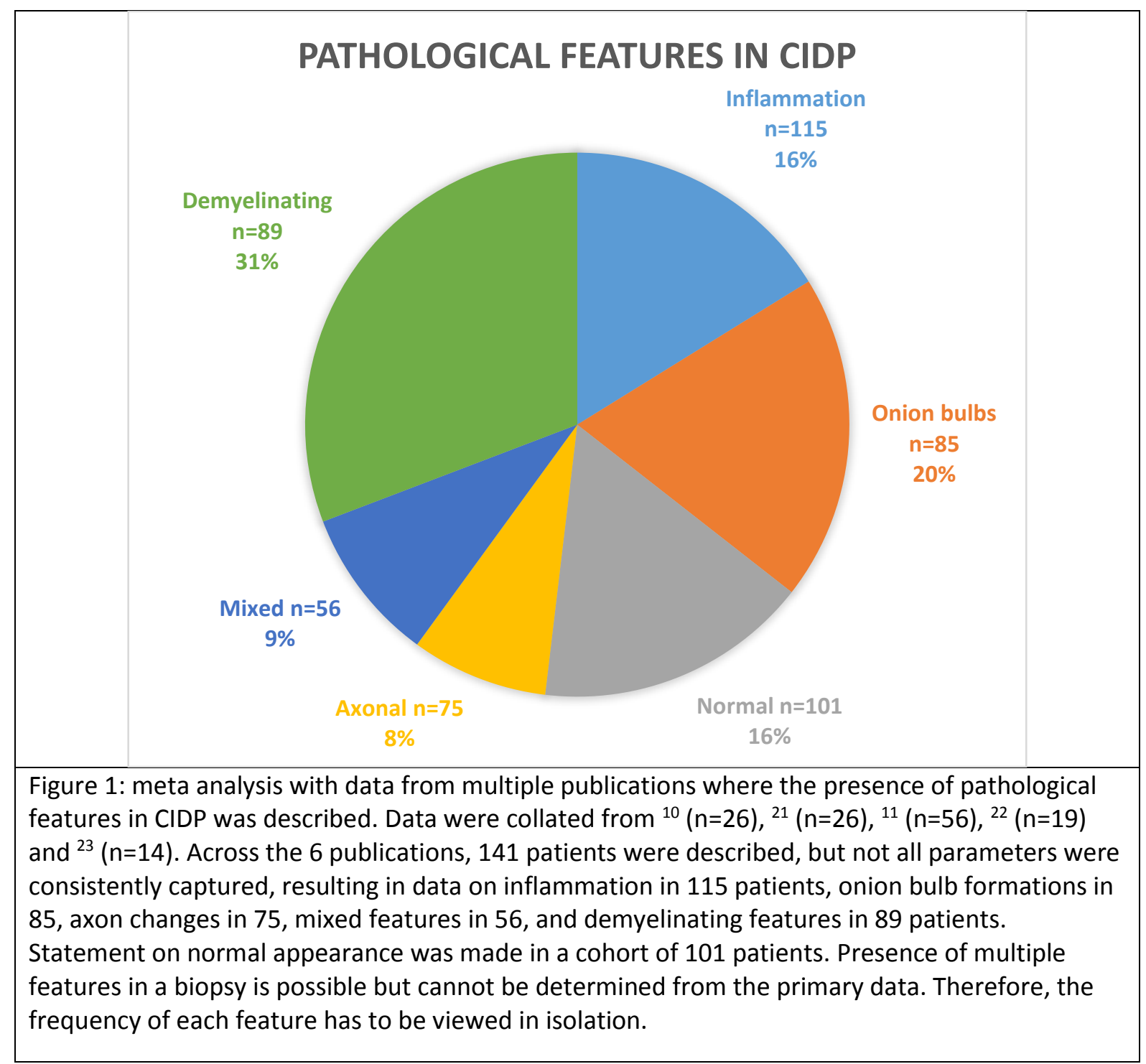

\section{Toxic neuropathies}

Toxic neuropathies are caused by occupational or environmental exposure, by medication, or nutrition. This paragraph does not cover those neuropathies caused by malnutrition or nutritional toxic causes such as alcoholic neuropathies. In the past, a significant proportion of toxic neuropathies had occupational or environmental causes, due to the widespread use of lead, arsenic, mercury, thallium, acrylamide, organophosphates, trichlorethylene, DDT, tetrachlorethane, pentachlorophenol ${ }^{24}$. In modern industrialised countries these toxins are subject to very strict civilian use and therefore work-related exposure has dramatically decreased, but they are on the rise in emerging economies where environmental pollution and occupational exposure are less strictly controlled. Medication-induced neuropathies have long been known for well-established drugs such as Amiodarone ${ }^{25}$ or Chloroquine ${ }^{26}$ and have recently become more prevalent, due to the development and availability of a multitude of increasingly sophisticated drugs, which have added to the spectrum of offending agents ${ }^{27,28}$. Recognising the causes of toxic neuropathies is essential as they are preventable and treatable. Clinically, the presentation of a toxic neuropathy can mimic hereditary, autoimmune, or metabolic neuropathies. Symptoms can include sensory, motor, or autonomic neuropathies. Neuropathological assessment, still regarded the gold standard of 
peripheral nerve analysis, can provide an accurate view of the natural history ranging from initial changes to end stage processes, such as Wallerian degeneration. The microscopic and ultrastructural analysis of these nerve biopsies may be able to identify the anatomical target of the toxin, such as axon changes (giant axonal neuropathy, retrograde degeneration), demyelination, Schwann cell morphology, interstitium and blood vessels, inflammatory infiltrates and the overall condition of the nerve with fibre density, regeneration clusters and remyelination ${ }^{29}$.

\section{Hereditary neuropathies}

This heterogeneous group is classified as hereditary motor and sensory neuropathy (HMSN, also known as Charcot-Marie-Tooth, CMT), hereditary sensory and autonomic neuropathies (HSAN) and hereditary motor neuropathies (HMN). As mentioned in the introduction, hereditary neuropathies are nowadays almost exclusively diagnosed by genetic testing.

- $\quad$ CMT1/HMSN1: this form is predominantly demyelinating and presents with a prominent reduction in nerve conduction velocity (NCV) (below $38 \mathrm{~m} / \mathrm{s}$ ).

- $\quad \mathrm{CMT2} / \mathrm{HSMN2}$ is predominantly axonal and most cases show only moderately reduced NCVs 30 .

- Intermediate CMT encompass cases with hereditary neuropathy and NCVs between 30 and $40 \mathrm{~m} / \mathrm{s}^{31}$.

- HMSN 4/CMT4 have an autosomal recessive inheritance and present clinically as demyelinating, often severe and rapidly progressive phenotype.

- HMSN X/CMTX may be inherited as a dominant or recessive form; male patients are usually more severely affected.

\section{Pathogenesis and genetics}

The first genetic lesion to be discovered in inherited neuropathies was the duplication in the short arm of chromosome 17, containing the peripheral myelin protein 22 (PMP22) gene ${ }^{32,33}$. The discovery of point mutations in GJB1, PMP22 and MPZ followed shortly afterwards and account for more than $70 \%$ of all cases of $\mathrm{CMT}^{34}{ }^{34}$. An overview of the most common forms of $\mathrm{CMT}$, the associated gene mutations and the relevant protein involved are shown in Table 5. The increasing availability of next generation sequencing technologies has resulted in the identification of more than $70 \mathrm{CMT}$-associated genes so far ${ }^{34}$. Interestingly, many genes mutated in HSNAs encode for proteins involved in endoplasmic reticulum development, maintenance and function ${ }^{35}$.

\section{Indication for nerve biopsies in suspected hereditary neuropathies}

With the advancement of genetic testing of neurological disorders including neuropathies, the number of nerve biopsy in the diagnosis of hereditary neuropathies has declined over time. Nowadays the indications for nerve biopsy in the context of a hereditary neuropathy is the exclusion of inflammatory components and where multiple aetiologies with a combination of inflammatory, toxic and genetic factors have to be dissected diagnostically.

\begin{tabular}{|l|l|l|l|l|l|}
\hline CMT type & $\begin{array}{l}\text { Most } \\
\text { commonly } \\
\text { mutated genes }\end{array}$ & $\begin{array}{l}\text { type of } \\
\text { mutation }\end{array}$ & compartment & $\begin{array}{l}\text { Other associated } \\
\text { phenotypes }\end{array}$ & OMIM \\
\hline CMT 1 & PMP22 & $\begin{array}{l}\text { chromosome } \\
17\end{array}$ & $\begin{array}{l}\text { Schwann cell } \\
\text { myelin }\end{array}$ & HNPP (see below) & 118220 \\
\hline
\end{tabular}




\begin{tabular}{|c|c|c|c|c|c|}
\hline CMT type & $\begin{array}{l}\text { Most } \\
\text { commonly } \\
\text { mutated genes }\end{array}$ & $\begin{array}{l}\text { type of } \\
\text { mutation }\end{array}$ & compartment & $\begin{array}{l}\text { Other associated } \\
\text { phenotypes }\end{array}$ & OMIM \\
\hline & $\begin{array}{l}\text { peripheral } \\
\text { myelin protein } \\
22\end{array}$ & $\begin{array}{l}\text { duplication; } \\
\text { point } \\
\text { mutation }\end{array}$ & & & \\
\hline & $\begin{array}{l}\text { GJB1 } \\
\text { Gap Junction } \\
\text { Protein, Beta 1, } \\
\text { 32kDa } \\
\text { (Connexin 32) } \\
\text { GJB1 }\end{array}$ & $\begin{array}{l}\text { Point } \\
\text { mutation }\end{array}$ & $\begin{array}{l}\text { Schwann cell } \\
\text { channel }\end{array}$ & CMTX & 302800 \\
\hline & $\begin{array}{l}\text { MPZ } \\
\text { Myelin protein } \\
\text { Zero or P0) }\end{array}$ & $\begin{array}{l}\text { point } \\
\text { mutations, }\end{array}$ & $\begin{array}{l}\text { Schwann cell } \\
\text { myelin sheath } \\
\text { structural } \\
\text { protein }\end{array}$ & $\begin{array}{l}\text { Dejerine-Sottas } \\
\text { syndrome (frame } \\
\text { shift), congenital } \\
\text { hypomyelinating } \\
\text { neuropathy }\end{array}$ & 159440 \\
\hline CMT 2 & $\begin{array}{l}\text { MFN2 } \\
\text { Mitofusin } 2\end{array}$ & $\begin{array}{l}\text { Point } \\
\text { mutation }\end{array}$ & $\begin{array}{l}\text { Neuronal } \\
\text { cytoplasm, } \\
\text { mitochondria }\end{array}$ & & 609260 \\
\hline CMTX & $\begin{array}{l}\text { GJB1 (see } \\
\text { above) }\end{array}$ & $\begin{array}{l}\text { Point } \\
\text { mutation }\end{array}$ & $\begin{array}{l}\text { Schwann cell } \\
\text { channel }\end{array}$ & CMT 1 (see above) & 302800 \\
\hline \multirow[t]{3}{*}{$\begin{array}{l}\text { CMT } \\
\text { intermediate } \\
\text { type }\end{array}$} & $\begin{array}{l}\text { INF2 } \\
\text { inverted formin } \\
2\end{array}$ & $\begin{array}{l}\text { Point } \\
\text { mutations }\end{array}$ & $\begin{array}{l}\text { Schwann cell } \\
\text { cytoplasm, } \\
\text { cytoskeleton }\end{array}$ & $\begin{array}{l}\text { Glomerulosclerosis, } \\
\text { focal segmental }\end{array}$ & 610982 \\
\hline & $\begin{array}{l}\text { NEFL } \\
\text { neurofilament } \\
\text { light chain }\end{array}$ & $\begin{array}{l}\text { Point } \\
\text { mutations }\end{array}$ & $\begin{array}{l}\text { Neuronal axon } \\
\text { cytoplasm, } \\
\text { axonal } \\
\text { transport }\end{array}$ & $\begin{array}{l}\text { CMT2E axonal or } \\
\text { demyelinating } \\
\text { form, CMT1F }\end{array}$ & $\begin{array}{l}607684, \\
607734, \\
118210\end{array}$ \\
\hline & $\begin{array}{l}\text { GDAP1 } \\
\text { ganglioside- } \\
\text { induced } \\
\text { differentiation- } \\
\text { associated } \\
\text { protein-1 }\end{array}$ & $\begin{array}{l}\text { Point } \\
\text { mutations }\end{array}$ & $\begin{array}{l}\text { Neuronal } \\
\text { cytoplasm, } \\
\text { mitochondria }\end{array}$ & $\begin{array}{l}\text { CMT2K and } \\
\text { CMT4A; autosomal } \\
\text { dominant CMT with } \\
\text { pyramidal } \\
\text { involvement }\end{array}$ & 607831 \\
\hline $\begin{array}{l}\text { Autosomal } \\
\text { recessive } \\
\text { demyelinating } \\
\text { CMT/HMSN } \\
\text { (HMSN } \\
\text { 4/CMT4 }\end{array}$ & $\begin{array}{l}\text { MTMR } \\
\text { myotubularin- } \\
\text { related protein } \\
\text { genes }\end{array}$ & $\begin{array}{l}\text { Point } \\
\text { mutations }\end{array}$ & $\begin{array}{l}\text { Schwann cell, } \\
\text { endosomal } \\
\text { sorting and } \\
\text { cell signalling }\end{array}$ & $\begin{array}{l}\text { X-linked } \\
\text { myotubular } \\
\text { myopathy }\end{array}$ & 603557 \\
\hline $\begin{array}{l}\text { Hereditary } \\
\text { neuropathy } \\
\text { with pressure } \\
\text { palsies (HNPP) }\end{array}$ & $\begin{array}{l}\text { PMP22 (see } \\
\text { above) }\end{array}$ & $\begin{array}{l}\text { Deletions } \\
\text { point } \\
\text { mutations }\end{array}$ & $\begin{array}{l}\text { Schwann cell } \\
\text { myelin }\end{array}$ & See above & 162500 \\
\hline \multicolumn{6}{|c|}{$\begin{array}{l}\text { Table 5: the most common genetic neuropathies, there causative genes, and the gene function in } \\
\text { relation to the cellular compartment. The related Online Mendelian Inheritance in Man (OMIM) } \\
\text { reference is given in the right column. }\end{array}$} \\
\hline
\end{tabular}

\section{Neuropathological findings in hereditary neuropathies}


CMT 1 can be caused by a variety of genetic mutations (see table 4 and for review ${ }^{34}$ ) and therefore also shows a degree of pathological variation ${ }^{36}$. Microscopically, there is a widening of the fascicle, caused by endoneurial proliferation of Schwann cells and fibroblasts. In contrast to CIDP, where a patchy distribution of pathological changes are seen, changes in CMT are homogeneous. Typically, the number of myelinated fibres is reduced and varies between patients and it correlates with the severity of the clinical phenotype ${ }^{37}$. Recurrent de- and remyelination leads to the formation of concentrically shaped Schwann cell processes (colloquially also described as onion bulbs). Whilst these are not specific for any type of de-and remyelination, they are very typical for CMT 1.

Hereditary neuropathy with liability to pressure palsy (HNPP), morphologically presenting as Tomaculous neuropathy shows concentrically thickened myelin sheaths with outfoldings, loops, or infoldings (tomacula), and are best visualised in semithin resin sections and teased fibre preparations ${ }^{38}$, and electron microscopy can demonstrate that the abnormal folding is caused by redundant myelin loops.

CMT 2 is characterized by a chronic loss predominantly affecting large myelinated fibres ${ }^{39}$. In CMT2 with MFN2 mutations, electron microscopy shows ultrastructural alterations of axonal mitochondria ${ }^{40}$. Onion bulbs are usually absent, regenerating nerve clusters are a common feature and the nerve is not hypertrophic.

Intermediate forms are characterised by a combination of Schwann cell onion bulb formation and clusters of regenerating axons; semithin resin sections and electron microscopy can demonstrate axonal degeneration.

CMT 4 (autosomal recessive CMT 1) is further subdivided into subgroups, with associated specific genetic mutations. Morphologically, they are heterogeneous, ranging from variable demyelination to complete absence of myelin. So-called focally folded myelin and Schwann cell basal lamina onion bulbs are characteristic features ${ }^{41}$.

Congenital hypomyelinating neuropathy (CHN) is an extreme form of Schwann cell neuropathy which may by caused by mutations in various genes which are otherwise involved in CMT1 and CMT4.

\section{Practice points}

- The clinical indication for nerve biopsies have shifted over the last two decades. Biopsies of genetic forms have gradually decreased and the main indications for nerve biopsies nowadays are suspected inflammatory, neoplastic infiltrative and amyloid neuropathies.

- A standardised assessment including paraffin sections with a panel of immunostainings and semithin resin sections are recommended. Ultrastructural examinations are useful to assess myelin abnormalities.

- Resin sections have a significant diagnostic value and therefore it is strongly recommended to fix a segment of the fresh specimen in glutaraldehyde and having access to adequate processing of such samples.

- The key questions to be addressed when reporting nerve biopsies are:

0 Is there evidence for inflammation (perivascular, endoneurial?)

0 Is there evidence of a neoplastic infiltrative process?

- Is the main pathology axonal or demyelinating?

$\circ$ Is amyloid present in the endoneurium or epineurium? 
Nerve biopsies: a practical approach

- If there is demyelination, is the cause genetic or inflammatory?

Figure legends:

Figure 1: neuropathological features of axonal neuropathies: cross sections of nerve biopsies on resin semithin sections stained with MBA-BF. The left column shows an overview (equivalent to the $5 \mathrm{X}$ objective) and the right column the same nerve at high magnification (equivalent to the $40 \mathrm{X}$ objective). A, B: nerve within normal limits, showing a population of large and small myelinated fibres. C, D: this nerve biopsy shows a mild loss of axons with no visible degenerating fibres. $E, F$ : this nerve biopsy shows a very severe chronic axon loss with only rare myelinating fibres remaining. No profiles of degenerating axons are seen. $\mathrm{G}, \mathrm{H}$ : this nerve biopsy shows an ongoing (active) axon degeneration. Arrowheads in $\mathrm{H}$ indicate degenerating axon profiles. I, J, this nerve with a moderately severe axon loss shows several regeneration clusters (arrowheads in J).

Figure 2: neuropathological features of vasculitic neuropathy: upper row alterations in the blood vessel with occlusion of the vessel wall (A), destruction of the vessel wall and infiltration by lymphocytes and monocytes $(B, C)$, and $D$ shows the infiltration of the vessel wall by CD3 positive $T$ cells.

$\mathrm{E}-\mathrm{H}$ : acute axonal neuropathy in a nerve with moderate axon loss. In this example, the vasculitic neuropathy is in early stages and has affected only a small proportion of the axons. F, semithin resin section showing a cross-section of a well populated nerve (large and small myelinated fibres). G, neurofilament staining showing large and small axons in a cross section. $\mathrm{H}$, frequent endoneurial macrophages are a feature of vasculitic neuropathies (longitudinal section). I-L, long-standing axonal neuropathy with frequent axon degeneration has led to a nearly complete depletion of myelinated $(\mathrm{J})$ and also unmyelinated (K) fibres. The neurofilament staining (K) labels large and small fibres and indicates a loss of both populations. L, macrophage activity in the same nerve (longitudinal section). $M-P$ : terminal stage of an axonal neuropathy with complete loss of myelinated fibres $(N)$, and the neurofilament staining $(O)$ indicates that unmyelinated fibres are also affected. The macrophage marker CD68 (P) shows only few residual macrophages at this terminally depleted nerve

Figure 3: amyloid neuropathy. A, longitudinal section H\&E staining. The centre of the nerve shows a small aggregate of amyloid, displacing the axons. The Congo red staining (B) highlights the same structures in the centre of the nerve. $C$, cross-section of same nerve, stained for neurofilament. There is loss of large and small axons.

Figure 4: nerve infiltration by $B$ cell lymphoma: a: the AB-PAS staining shows the dense mononuclear infiltrate, and to the insert demonstrates the CD20 immunoreactivity of the infiltrate. The PGP 9.5 staining (B) labels axons and demonstrates the displacement of remaining viable axons by the infiltrates. C, Ki67 immunolabelling demonstrates the excessive proliferative activity of the lymphoma

Figure 5: lepromatous neuropathy: A, widespread inflammatory infiltrates of the endoneurium, perineurium and epineurium. The infiltrates are macrophages $(B, C D 68)$ which are filled with acid fast bacilli (not shown). The nerve fascicles (right half of the image) is also infiltrated by macrophages (B) and shows axon loss (C) involving fibres of all sizes (no axons detectable in this cross-section). 
Nerve biopsies: a practical approach

15 | P a g e 


\section{References}

1 Sommer, C. et al. 147th ENMC international workshop: guideline on processing and evaluation of sural nerve biopsies, 15-17 December 2006, Naarden, The Netherlands. Neuromuscul Disord 18, 90-96, doi:S0960-8966(07)00721-3 [pii]

10.1016/j.nmd.2007.08.010 (2008).

2 Amoiridis, G., Schols, L., Ameridis, N. \& Przuntek, H. Motor fibers in the sural nerve of humans. Neurology 49, 1725-1728 (1997).

3 Jacobs, J. M. \& Love, S. Qualitative and quantitative morphology of human sural nerve at different ages. Brain 108 ( Pt 4), 897-924 (1985).

4 Sommer, C. L. et al. Peripheral Nerve Society Guideline on processing and evaluation of nerve biopsies. J Peripher Nerv Syst 15, 164-175, doi:10.1111/j.1529-8027.2010.00276.x (2010).

5 Sommer, C. \& Toyka, K. Nerve biopsy in chronic inflammatory neuropathies: in situ biomarkers. J Peripher Nerv Syst 16 Suppl 1, 24-29, doi:10.1111/j.1529-8027.2011.00301.x (2011).

6 Weis, J., Brandner, S., Lammens, M., Sommer, C. \& Vallat, J. M. Processing of nerve biopsies: a practical guide for neuropathologists. Clin Neuropathol 31, 7-23, doi:9316 [pii] (2012).

7 Brandner, S. et al. Tissue pathways for non-neoplastic neuropathology specimens. The Royal College of Pathologists (2015).

8 Collins, M. P. et al. Peripheral Nerve Society Guideline on the classification, diagnosis, investigation, and immunosuppressive therapy of non-systemic vasculitic neuropathy: executive summary. J Peripher Nerv Syst 15, 176-184, doi:10.1111/j.1529-8027.2010.00281.x (2010).

9 Ropper, A. H. The Guillain-Barre syndrome. N Engl J Med 326, 1130-1136, doi:10.1056/nejm199204233261706 (1992).

10 Dyck, P. J. et al. Chronic inflammatory polyradiculoneuropathy. Mayo Clin Proc 50, 621-637 (1975).

11 Barohn, R. J., Kissel, J. T., Warmolts, J. R. \& Mendell, J. R. Chronic inflammatory demyelinating polyradiculoneuropathy. Clinical characteristics, course, and recommendations for diagnostic criteria. Arch Neurol 46, 878-884 (1989).

12 Kawagashira, Y. et al. IgM MGUS anti-MAG neuropathy with predominant muscle weakness and extensive muscle atrophy. Muscle Nerve 42, 433-435, doi:10.1002/mus.21741 (2010).

13 Vital, C. et al. Uncompacted myelin lamellae in polyneuropathy, organomegaly, endocrinopathy, M-protein and skin changes syndrome. Ultrastructural study of peripheral nerve biopsy from 22 patients. Acta Neuropathol 87, 302-307 (1994).

14 Nobile-Orazio, E. et al. Frequency and clinical correlates of anti-neural IgM antibodies in neuropathy associated with IgM monoclonal gammopathy. Ann Neurol 36, 416-424, doi:10.1002/ana.410360313 (1994).

15 Ramchandren, S. \& Lewis, R. A. An update on monoclonal gammopathy and neuropathy. Curr Neurol Neurosci Rep 12, 102-110, doi:10.1007/s11910-011-0237-4 (2012).

16 Kyle, R. A. \& Gertz, M. A. Primary systemic amyloidosis: clinical and laboratory features in 474 cases. Seminars in hematology 32, 45-59 (1995).

17 Dohrn, M. F. et al. Diagnostic hallmarks and pitfalls in late-onset progressive transthyretinrelated amyloid-neuropathy. J Neurol 260, 3093-3108, doi:10.1007/s00415-013-7124-7 (2013).

18 Plante-Bordeneuve, V. \& Said, G. Familial amyloid polyneuropathy. Lancet Neurol 10, 10861097, doi:10.1016/s1474-4422(11)70246-0 (2011).

19 Reilly, M. M. \& King, R. H. Familial amyloid polyneuropathy. Brain Pathol 3, 165-176 (1993). 
20 Weis, J., Alexianu, M. E., Heide, G. \& Schroder, J. M. Renaut bodies contain elastic fiber components. J Neuropathol Exp Neurol 52, 444-451 (1993).

21 Prineas, J. W. \& McLeod, J. G. Chronic relapsing polyneuritis. J Neurol Sci 27, 427-458 (1976).

22 Small, G. A. \& Lovelace, R. E. Chronic inflammatory demyelinating polyneuropathy. Semin Neurol 13, 305-312, doi:10.1055/s-2008-1041139 (1993).

23 Krendel, D. A., Parks, H. P., Anthony, D. C., St Clair, M. B. \& Graham, D. G. Sural nerve biopsy in chronic inflammatory demyelinating polyradiculoneuropathy. Muscle Nerve 12, 257-264, doi:10.1002/mus.880120402 (1989).

24 Barnes, J. M. Toxic chemicals and peripheral neuropathy: experimental studies. Proc $R$ Soc Med 62, 205-208 (1969).

25 Orr, C. F. \& Ahlskog, J. E. Frequency, characteristics, and risk factors for amiodarone neurotoxicity. Arch Neurol 66, 865-869, doi:66/7/865 [pii]

10.1001/archneurol.2009.96 (2009).

26 Estes, M. L. et al. Chloroquine neuromyotoxicity. Clinical and pathologic perspective. Am J Med 82, 447-455, doi:0002-9343(87)90444-X [pii] (1987).

27 Manji, H. Toxic neuropathy. Curr Opin Neurol 24, 484-490, doi:10.1097/WCO.0b013e32834a94b6 (2011).

28 Weimer, L. H. \& Sachdev, N. Update on medication-induced peripheral neuropathy. Curr Neurol Neurosci Rep 9, 69-75 (2009).

29 Scelsi, R. \& Candura, S. M. [Occupational toxic neuropathies: morphology in peripheral nerve biopsies]. G Ital Med Lav Ergon 34, 410-419 (2012).

30 Harding, A. E. \& Thomas, P. K. The clinical features of hereditary motor and sensory neuropathy types I and II. Brain 103, 259-280 (1980).

31 Davis, C. J., Bradley, W. G. \& Madrid, R. The peroneal muscular atrophy syndrome: clinical, genetic, electrophysiological and nerve biopsy studies. I. Clinical, genetic and electrophysiological findings and classification. Journal de genetique humaine 26, 311-349 (1978).

32 Lupski, J. R. et al. DNA duplication associated with Charcot-Marie-Tooth disease type 1A. Cell 66, 219-232 (1991).

33 Raeymaekers, P. et al. Duplication in chromosome 17p11.2 in Charcot-Marie-Tooth neuropathy type 1a (CMT 1a). The HMSN Collaborative Research Group. Neuromuscul Disord 1, 93-97 (1991).

34 Rossor, A. M., Polke, J. M., Houlden, H. \& Reilly, M. M. Clinical implications of genetic advances in Charcot-Marie-Tooth disease. Nat Rev Neurol 9, 562-571, doi:10.1038/nrneurol.2013.179 (2013).

35 Hubner, C. A. \& Kurth, I. Membrane-shaping disorders: a common pathway in axon degeneration. Brain 137, 3109-3121, doi:10.1093/brain/awu287 (2014).

36 Vallat, J. M. \& Mathis, S. in Peripheral nerve disorders: Pathology and genetics Vol. 1 (ed J.M Vallat, Weis, J.) 62-72 (Wiley and Sons, 2014).

37 Hattori, N. et al. Demyelinating and axonal features of Charcot-Marie-Tooth disease with mutations of myelin-related proteins (PMP22, MPZ and Cx32): a clinicopathological study of 205 Japanese patients. Brain 126, 134-151 (2003).

38 Madrid, R. E., Jaros, E., Cullen, M. J. \& Bradley, W. G. Genetically determined defect of Schwann cell basement membrane in dystrophic mouse. Nature 257, 319-321 (1975).

39 Schröder, J. M., Weis, J. \& Senderek, J. in Peripheral nerve disorders: Pathology and genetics Vol. 1 (ed J.M Vallat, Weis, J.) 72-84 (Wiley and Sons, 2014).

40 Verhoeven, K. et al. MFN2 mutation distribution and genotype/phenotype correlation in Charcot-Marie-Tooth type 2. Brain 129, 2093-2102, doi:10.1093/brain/awl126 (2006).

41 Claeys, K. G., Lammens, M., Senderek, J. \& Weis, J. in Peripheral nerve disorders: Pathology and genetics Vol. 1 (ed J.M Vallat, Weis, J.) 85-101 (Wiley and Sons, 2014). 
Nerve biopsies: a practical approach

\section{Acknowledgements:}

I would like to thank Zane Jaunmuktane, Division of Neuropathology for critical reading and input. 